\title{
SOURCES AND MOVEMENT OF ICEBERGS IN THE SOUTH-WEST ROSS SEA, ANTARCTICA
}

\author{
by \\ Harry Keys* \\ (Commission for the Environment, Wellington, New Zealand)
}

and

Dennis Fowler

(Division of Information Technology, Department of Scientific and Industrial Research, Lower Hutt, New Zealand)

\section{ABSTRACT}

The shape, surface features, composition, and thickness of icebergs trapped annually in a $200 \mathrm{~km}$ long coastal strip of fast ice have been examined to determine their sources and movement. The thin western ice front of the Ross Ice Shelf seems to produce about $40 \%$ of the icebergs while local glaciers produce the remainder. The ice-shelf icebergs are carried west towards Ross Island then north up the western side of the Ross Sea. A small proportion of them gets trapped mainly by grounding on shallow areas of the sea floor which protrude across the regional long-shore currents.

\section{INTRODUCTION}

Iceberg production is a major factor in the mass balance of the Antarctic ice sheet and hence influences ice dynamics, especially for ice shelves. With climate change impending, it has become necessary to determine the quantities and sources of icebergs in more detail in order to understand how ice shelves will react to significantly different environmental conditions. Recent large calvings of the largest ice shelves may substantially alter strain-rates near the ice fronts with possible implications up-flow. Identification of specific calving sites will allow the factors which affect calving rates to be understood better.
Knowledge of the main sources and movement patterns of icebergs in the Ross Sea will also allow the degree of hazard posed by drifting icebergs to be assessed better. In addition, it will give useful information on sea currents and other forces causing the icebergs to move.

This paper introduces results from five seasons of monitoring icebergs trapped annually in fast sea ice in the south-west Ross Sea and brings together previous work for the whole Ross Sea sector.

\section{ICEBERG QUANTITIES}

Icebergs in a $200 \mathrm{~km}$ long strip of fast ice south of Nordenskjöld Ice Tongue (Figs 1 and 2) have been monitored between 1983 and 1987. This study area was briefly examined for icebergs from a helicopter in November 1983 with short ground visits to two places, examined in detail in November 1984 using helicopter-based near-vertical aerial photography and ground visits, and photographed obliquely from a height of $2400 \mathrm{~m}$ using a C-130 aircraft in December 1984, 1985, 1986, and 1987. Helicopter-based aerial photography and SPOT imagery were also used to count over half the icebergs in December 1987.

These different logistic methods affect iceberg detectability. Preliminary measurements of iceberg lengths, widths, and size distributions, and comparisons of the total numbers of icebergs detected by various methods give a

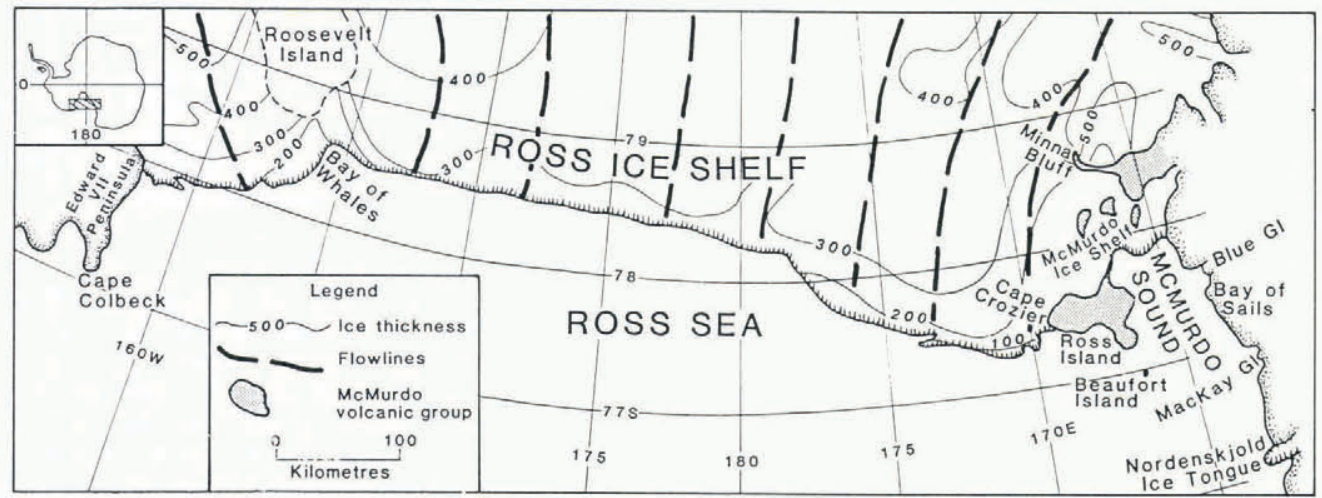

Fig. 1. The northern part of the Ross Ice Shelf showing ice thickness and flow lines (after Bentley, 1985; Jacobs and others, 1986), and the distribution of McMurdo Volcanic Group rocks on nearby land.

* Present address: Science Directorate, Department of Conservation, P.O. Box 10-420, Wellington, New Zealand. 


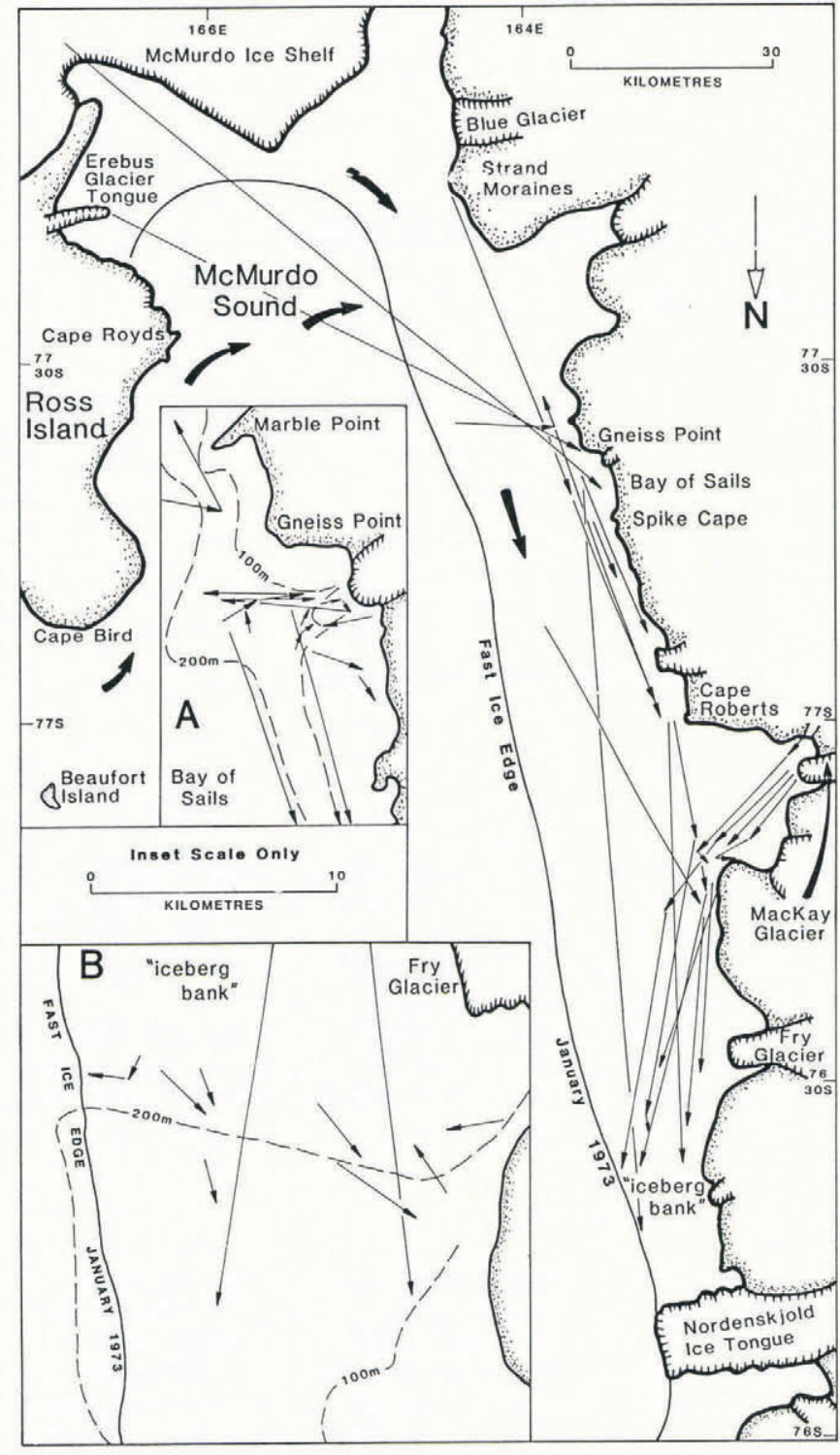

Fig. 2. Iceberg-movement patterns in the fast-ice zone, determined by tracking identifiable icebergs over successive seasons or by knowing the source of locally derived icebergs. The net drift of the iceberg that broke off Erebus Glacier Tongue in 1911 and documented by R.F. Scott is also shown. Solid arrows show known current directions. Insets show local movements in the Bay of Sails (A) and "Iceberg bank" (B).

good indication of the percentage of icebergs detected by those methods. Helicopter-based aerial photography seems the most reliable remote-sensing method (about 90\%), although photographing through open doors of a C-130 aircraft with large-format cameras and low sun angles improves resolution and detectability probably to well over $80 \%$. Close to $100 \%$ of icebergs $30 \mathrm{~m}$ or longer were visible on the SPOT image. Table I lists the numbers of icebergs actually detected, estimates of total detectability, and estimated numbers of icebergs present.

The quantity of icebergs present varied significantly from season to season (Table I). The maximum number detected in any one season was 455 in 1984, when almost 500 icebergs were likely to have been present. About $40 \%$ fewer icebergs would have been present in 1987. This variation is consistent with observations (e.g. Jacobs and others, 1986) that iceberg production is not regular in time. The large quantity of icebergs means that discussions of iceberg source and movement need to be based mainly on generalizations.

The spatial distribution of icebergs in fast ice is more consistent from year to year. Some tens of icebergs normally
TABLE I, SUMMARY OF ICEBERG MONITORING FOR THE FAST-ICE ZONE OFF SOUTH VICTORIA LAND SOUTH OF NORDENSKJÖLD ICE TONGUE

Season

$$
1984-85
$$

$1985-86$

$1986-87$

$1987-88$

$\begin{array}{lllll}\text { Number of icebergs } & 448 & 315 & 275 & 261\end{array}$

detected $(N)$

Estimated percentage $95 \pm 5 \quad 70 \pm 10 \quad 80 \pm 10 \quad 90 \pm 10$ of icebergs detected

Estimated number of icebergs present

Number of tabular 31 30 32

icebergs (as a percentage of $N$

ground in the Bay of Sails and around Cape Roberts, and significant numbers ground elsewhere, although fast ice overlying water deeper than $200 \mathrm{~m}$ seldom has icebergs (Keys, 1985). The annual count in $22 \mathrm{~km}^{2}$ of fast ice in the Bay of Sails ranged from 62 to 132 icebergs (average 90 , standard deviation 26). Details of such variations will be presented elsewhere.

Fewer icebergs are present per unit area in the pack ice. Romanov (1984) showed that iceberg concentration averages only five-six icebergs per $1000 \mathrm{~km}^{2}$ in this area, and decreases towards the centre of the Ross Sea.

\section{ICEBERG CHARACTERISTICS}

Shapes and composition

On average, $32 \%$ of icebergs detected were tabular in shape (Table I). This percentage varied little between years despite the large variation in iceberg quantities. The proportion of different types of tabular iceberg (Keys, 1986) identifiable as being produced by a particular type of floating land ice can be assumed to indicate the proportion of the local iceberg population produced from that source.

In 1984, $40 \%$ of these tabular icebergs had featureless, flat-topped upper surfaces and were composed of stratified snow grading down into firn and ice. Density profiles were obtained by taking SIPRE cores up to $1 \mathrm{~m}$ long from the sides of two fresh-looking tabular icebergs $15-20 \mathrm{~m} \mathrm{high}$ and determining the mass of measured volumes. One iceberg (CR-32) was tilted, giving access to ice $50 \mathrm{~m}$ stratigraphically below the original top surface. Densities were similar to the density profile of the Ross Ice Shelf (Fig. 3). A third tabular iceberg (84-38) was only $3 \mathrm{~m}$ high and had a profile similar to that of the McMurdo Ice Shelf. Three truncated sets of vehicle tracks across it confirmed this source (Keys, 1985).

The remaining $60 \%$ of tabular icebergs contained firn and ice only (and some contained significant amounts of dirt). Most had uneven (ablated) upper surfaces. These icebergs, therefore, were derived from glaciers whose firn line is some distance above sea-level.

\section{Dirt content}

The lithology and sedimentary environment of dirt in icebergs may give information on the dirt source and dynamics of the parent glacier. A water-worn, irregularshaped iceberg $(83 \mathrm{GH}-22)$ in Granite Harbour contained several parallel layers of dirt, up to $1 \mathrm{~m}$ thick, separated by clean ice. This very poorly sorted debris (Table II) would probably have been derived from erosion and entrainment at the glacier sole. The provenance of the dirt suggests a south Victoria Land glacier source.

In 1983, an irregular-shaped iceberg (83BS-42) was found to contain a layer of predominantly volcanogenic sand, parallel to, and about $3 \mathrm{~m}$ below a small remnant of the original tabular surface. Sand-grain mineralogy showed that the dirt consisted mainly of basaltic glass and rock fragments, with a minor amount of basement granitic 


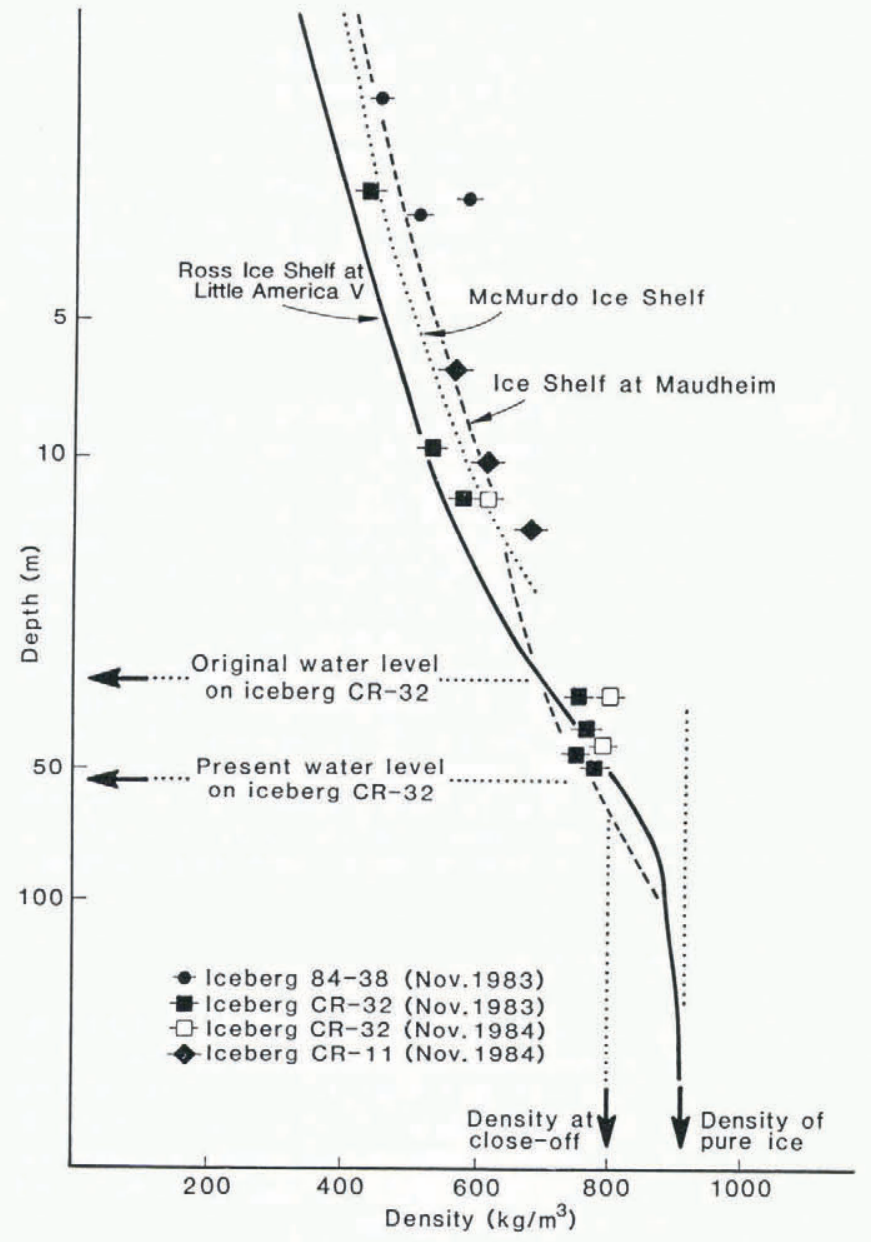

Fig. 3. Vertical density profiles in three ice shelves and three icebergs (after Keys, 1985).

material (Table II). This is consistent with a source rich in McMurdo Volcanic Group rocks somewhere in the northwestern part of the Ross Ice Shelf (Fig. 1). The physical character of the $10 \mathrm{~mm}$ thick, ice-rich dirt layer, and its original location in the upper part of a layered snow-pack, together with its grain-size characteristics and moderate degree of sorting (Table II), indicate that it was deposited

TABLE II. ORIGIN OF SAND GRAINS (PROVENANCE) FROM POINT COUNTS OF GRAIN MINERALOGY AND GRAIN-SIZE ANALYSIS OF TWO ICEBERG SEDIMENTS

Iceberg number

$83 \mathrm{GH}-22$

83BS-42

Provenance (\%) from sand-grain mineralogy

Basement

Beacon Supergroup

25

1

Ferrar dolerite

46

Volcanic rocks

$<1$

Grain-size analysis (Folk)

Graphic mean grain-size

( $\phi$ units)

Graphic standard deviation

Sorting and lithological description by wind in the accumulation zone of the parent glacier. The $3 \mathrm{~m}$ depth of burial, a snow-accumulation rate of $0.2 \mathrm{~m} /$ year water equivalent and ice velocities of up to $500 \mathrm{~m} /$ year (Bentley, 1985) suggest that the dirt would have moved only a few kilometres from where it was incorporated. The most likely source is at the eastern end of Ross Island (e.g. Cape Crozier) where granitic and other erratics mix with the local volcanic rocks up to about $500 \mathrm{~m}$ above sea-level.

\section{Thickness and volume}

An iceberg's thickness can be used to help identify its source, since melt rates are slow in the cold coastal waters, only $0.1-1$ deg above freezing. Sounding water depths beside grounded icebergs or reference to bathymetric data (Pyne and others, 1985) enables their drafts and hence thicknesses to be determined. Soundings were made through holes drilled in the fast ice using a weighted wire line and are accurate to about $1 \%$.

Most of the flat-topped tabular icebergs with stratified snow-packs were between 50 and $100 \mathrm{~m}$ thick. The total volume of these was about $0.057 \mathrm{~km}^{3}$. A very few tabular icebergs had heights (freeboards) as low as $2 \mathrm{~m}$, were probably less than $20 \mathrm{~m}$ thick, and had a total volume of less than $0.0001 \mathrm{~km}^{3}$. The combined volume of all the 1984 icebergs with some snow-pack, including irregular-shaped tabular remnants, would have been much less than $0.1 \mathrm{~km}^{3}$.

Soundings of up to $273 \mathrm{~m}$ were obtained alongside uneven tabular icebergs $300 \mathrm{~m}$ thick grounded along the southern edge of "Iceberg bank" (unofficial name used by Keys (1985)) north-east of Fry Glacier Tongue (Fig. 2). Mackay Glacier Tongue, which is $250-350 \mathrm{~m}$ thick (personal communication from A. Macpherson), is the source of most of these icebergs due to a calving of $3 \mathrm{~km}^{2}$ in 1982-83 (Keys, 1985).

\section{ICEBERG SOURCES}

\section{Ross Ice Shelf}

The western ice front of the Ross Ice Shelf within $200 \mathrm{~km}$ of Cape Crozier is probably the source of most of the flat-topped tabular icebergs in the study area. The characteristics of these icebergs are similar to this part of the ice shelf. Thicknesses at the ice front here are close to or less than $100 \mathrm{~m}$ (Fig. 1). Furthermore, recent minor calving of the ice shelf appears to have been most prevalent in the area west of $178^{\circ} \mathrm{E}$ (Jacobs and others, 1986). Such calving appears to have been less frequent in the Bay of Whales area, the only other place on the ice shelf where thicknesses are likely to be much less than $100 \mathrm{~m}$. A western Ross Ice Shelf source is also consistent with possible sources of volcanogenic dirt and ice-flow lines along which such dirt would be carried to the ice front (Fig. 1).

Only a small proportion of icebergs calved from the ice shelf appear to get trapped in the study area. A discrepancy of $0.3 \mathrm{~km} /$ year between ice velocity and apparent advance of the ice front (Jacobs and others, 1986) suggests an annual production of up to $6 \mathrm{~km}^{3}$ at the western ice front. This is much greater than the volume of Ross Ice Shelf icebergs $\left(<0.1 \mathrm{~km}^{3}\right)$ trapped annually in the study area.

\section{Local glaciers}

Glaciers in the vicinity of the study area are the sources of most, if not all, of the other tabular icebergs. About $30 \%$ of such icebergs were traced unambiguously, by direct observations of calving or by comparing vertical aerial photography, or by other means (Keys, 1985), to Mackay and New Glacier Tongues, Wilson Ice Piedmont, and eastern McMurdo Ice Shelf. Observations of calving and surface characteristics including moraine indicate that Blue Glacier, the dirt-covered part of McMurdo Ice Shelf, Strand Moraines, Bowers and Oates Ice Piedmonts, and Ferrar Glacier also contribute to the local iceberg population.

\section{ICEBERG MOVEMENT}

Regional patterns

Iceberg drift near the Antarctic coast is dominated by 


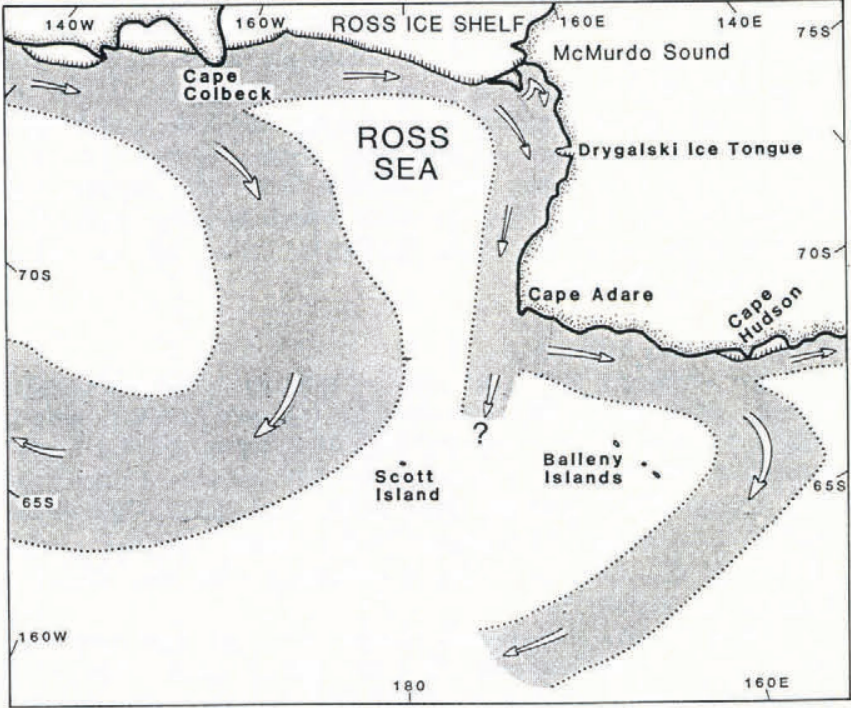

Fig. 4. Probable main iceberg-drift patterns in the Ross Sea sector.

the East Wind Drift current flowing counter-clockwise around the continent (Budd, in press). Tchernia and Jeannin (1983) showed that sea-floor and coastal topography also have a major influence, while the divergent area between the East and West Wind Drifts has relatively little effect. They tracked six icebergs drifting westward in the East Wind Drift towards the Ross Sea and then north into the Antarctic Circumpolar Current (West Wind Drift) in permanent "recurvature" currents. These "U-turn" currents are diverted from the coastal current by the continental shelf break north of Capes Colbeck and Hudson (Fig. 4). Although there are few records, the "Ross Sea shelf break" recurvature pattern means that probably few icebergs enter the Ross Sea from the east. This would preclude icebergs derived from floating land ice east of the Ross Sea from being present in significant quantities in the study area in the south-west Ross Sea.

Within the Ross Sea, strong deep-reaching currents set west along the front of the Ross Ice Shelf, turn north up the Victoria Land coast, and exit the Ross Sea around Cape Adare (Keys, 1984). Slow-moving, sub-surface meridional flows and shallow, local wind-driven currents may influence sea-ice movement but will have little effect on the thicker icebergs. Icebergs that calved from the eastern Ross Ice Shelf in the austral spring of 1987 during the calving of the giant B-9 iceberg have drifted westward along the ice front within about $20 \mathrm{~km}$ of it (written communication from U.S. Navy-NOAA Joint Ice Center, February 1988) at speeds of up to $10 \mathrm{~km} / \mathrm{d}$, consistent with Figure 4 .

Icebergs from the western Ross Ice Shelf are therefore carried towards the study area. As they approach Victoria Land, they mix with the locally derived icebergs, possibly in local gyral circulations in McMurdo Sound and south of Drygalski Ice Tongue. Thus, the mean concentration of icebergs (Romanov, 1984) and the degree of iceberg hazard in the pack-ice zone increase towards the west.

The icebergs continue north up the western Ross Sea. A drift path possibly $100-200 \mathrm{~km}$ wide (Fig. 4) is suggested by Romanov's (1984) mapping of iceberg concentrations. In the fast-ice zone, the positions of a large number of specific icebergs have been identified in successive years moving generally north (Fig. 2), consistent with the current pattern outlined above. Seasonal drifts of up to $100 \mathrm{~km}$ have been measured (Fig. 2) which, given an open-water season normally about 2-3 months long, suggests drift rates of $1-2 \mathrm{~km} / \mathrm{d}$, including possible time spent aground.

A zone of higher concentrations of icebergs protrudes north-north-east of Cape Adare (Romanov, 1984). Budd (in press) also noted that icebergs drift northward east of the Balleny Islands. This may be due to a northward extension of the western Ross Sea iceberg path (Fig. 4), possibly due to a divergence of the regional current there caused by the Balleny Islands.

\section{Local patterns}

Most local concentrations of icebergs along the south Victoria Land coast are due to icebergs grounding on shallow areas of the sea floor (Keys, 1985). At "Iceberg bank" (Fig. 2) and Cape Roberts, the $200 \mathrm{~m}$ contour protrudes across the regional long-shore current. Several drifts approximately normal to the coast in the Bay of Sails (Fig. 2) show that motion is directed more towards the shore here than elsewhere, probably due to both the circulation pattern (both onshore and long-shore currents) and sea-floor topography in McMurdo Sound. Icebergs are apparently trapped in the bay by an eddy-like feature in the deeper water at the south end as well as by shallows to the north and west (Fig. 2). The Coriolis force, to the left of accelerating motion, would reinforce coastward drifts as the currents accelerate north across the shallowing sea floor.

\section{ACKNOWLEDGEMENTS}

We thank $K$. Williams, K. Piddington, P. Ellis, M. McDonnell, J. Gilbert, and our respective departments for assisting with field work and supporting this work. We are also grateful to the Antarctic Division, Department of Scientific and Industrial Research, the New Zealand Air Force, and the United States Navy for logistic support, and to P. Robinson for the dirt analyses.

\section{REFERENCES}

Bentley, C.R. 1985. Glaciological evidence: the Ross Sea sector. In Glaciers, Ice Sheets and Sea Level: Effect of a $\mathrm{CO}_{2}$-induced Climatic Change; report of a Workshop held in Seattle, Washington September 13-15, 1984. Washington, DC, U.S. Department of Energy, 178-196.

Budd, W.F. In press. The Southern Hemisphere circulation of atmosphere, ocean and sea ice. In Proceedings of the Second International Conference on Southern Hemisphere Meteorology, 1-5 Dec., 1986, Wellington, New Zealand. Boston, MA, American Meteorological Society.

Jacobs, S.S., D.R. MacAyeal, and J.L. Ardai, jr. 1986. The recent advance of the Ross Ice Shelf, Antarctica. $J$. Glaciol., 32(112), 464-474.

Keys, J.R. 1984. Antarctic marine environments and offshore oil. Wellington, New Zealand Commission for the Environment.

Keys, J.R. 1985. Icebergs off south Victoria Land, Antarctica. N.Z. Antarct. Rec., 6(2), 1-7.

Keys, J.R. 1986. Towards a new shape classification of Antarctic icebergs. Iceberg Res., 12, 15-19.

Pyne, A.R., B.L. Ward, A.J. Macpherson, and P.J. Barrett. 1985. McMurdo Sound bathymetry, 1:250000. N.Z. Oceanogr. Inst. Chart. Misc. Ser., 62.

Romanov, A.A. 1984. L'dy Yuzhnogo okeana i usloviya sudokhodstva [Ice of the Southern Ocean and conditions for shipping]. Leningrad, Gidrometeoizdat.

Tchernia, P. and P.F. Jeannin. 1983. Quelques aspects de la circulation océanique Antarctique révélés par l'observation de la dérivé d'icebergs (1972-1983). Paris, Muséum National d'Histoire Naturelle. 